\title{
PENERAPAN SISTEM INTEGRATED RAHARJA MULTIMEDIA E-PORTFOLIO (iRME) CV ONLINE PADA PERGURUAN TINGGI RAHARJA
}

\author{
Untung Rahardja ${ }^{1}$ \\ Muhamad Yusup ${ }^{2}$ \\ Erni Astuti ${ }^{3}$ \\ e-mail : untung@raharja.info,yusup@raharja.info,erni.astuti@raharja.info
}

Diterima : 27 Nopember 2013 / Disetujui: 11 Desember 2013

\begin{abstract}
Developments in technology, especially Internet technology has supported to provide various types of services that can be accessed easily, quickly, efficiently, whenever and wherever, as well as allowing the use of e-portfolios. E-Portfolio is based on the application of advanced users to store, organize, and share items that represent the individual learner. Therefore, making an application $e$-portfolio system is highly recommended right. With methods based system online, the e - portfolio system will be very easy to use. E-portfolio is called iRME in Perguruan Tinggi Raharja. In this article described the problems that arise and solving the problem examined. In addition there are 5 ( five ) advantages of this application. In the implementation of the prototype view of iRME application. It can be concluded that the contribution iRME system can accommodate and facilitate private lifetime collection efforts Pribadi Raharja in personal portfolios. By implementing iRME on Perguruan Tinggi Raharja expected Pribadi Raharja to ease in making the Curriculum Vitae ( $C V$ ) of quality .
\end{abstract}

Keywords: iRME, e-portofolio, Curriculum Vitae (CV).

1. Dosen Jurusan Sistem Informasi, STMIK Raharja

Jl. Jend Sudirman No. 40 Modern Cikokol-Tangerang Telp. 5529692

2. Dosen Jurusan Sistem Informasi, STMIK Raharja

Jl. Jend Sudirman No. 40 Modern Cikokol-Tangerang Telp. 5529692

3. Mahasiswa Jurusan Sistem Informasi, STMIK Raharja

Jl. Jend Sudirman No. 40 Modern Cikokol-Tangerang Telp. 5529692 


\begin{abstract}
ABSTRAKSI
Perkembangan teknologi terutama teknologi internet telah mendukung keinginan untuk menyediakan berbagai jenis layanan yang dapat diakses dengan mudah, cepat, efisien, kapanpun dan dimanapun, begitu pula memungkinkan penggunaan e-portfolio. EPortofolio adalah aplikasi yang berpusat pada pengguna canggih untuk menyimpan, mengorganisir, dan berbagi item yang mewakili pelajar individu. Oleh karena itu, pembuatan sebuah aplikasi sistem e-portfolio yang tepat sangat disarankan. Dengan metode sistem berbasis online, sistem e-portfolio akan sangat mudah untuk digunakan. Eportfolio itu disebut iRME di Perguruan Tinggi Raharja.Dalam artikel ini dijelaskan masalah-masalah yang timbul serta pemecahan masalah yang diteliti. Selain itu terdapat 5 (lima) keunggulan dari aplikasi ini. Pada implementasinya ditampilkan tampilan prototype dari aplikasi iRME. Maka dapat disimpulkan bahwa kontribusi sistem iRME dapat mengakomodir dan memfasilitasi Pribadi Raharja dalam upaya lifetime pengumpulan portofolio pribadi. Dengan mengimplementasikan iRME pada Perguruan Tinggi Raharja diharapkan dapat mempermudah Pribadi Raharja dalam membuat Curriculum Vitae (CV) yang berkualitas.
\end{abstract}

Kata kunci: iRME, e-portofolio, Curriculum Vitae (CV).

\title{
PENDAHULUAN
}

Dengan perkembangan teknologi informasi yang sedemikian cepatnya telah membawa dunia memasuki era baru yang lebih cepat dari yang pernah dibayangkan sebelumnya. Perkembangan teknologi ini membawa perubahan dalam berbagai bidang kehidupan manusia. Salah satu hasil dari kemajuan teknologi adalah dihasilkannya komputer sebagai alat bantu manusia dalam melakukan pekerjaan dan juga internet sebagai sarana komunikasi penghubung yang digunakan melalui komputer. Teknologi akan terus berkembang. Teknologi informasi yang kuat akan menjadi keunggulan kompetitif bagi perusahaan. Bagi organisasi yang ingin maju dan berkembang, tidak ada alasan untuk tidak menggunakan teknologi sepanjang hal itu dapat mempermudah perusahaan menyesuaikan diri dengan lingkungannya.

Memasuki era globalisasi dengan pasar terbuka, persaingan global, perubahan-perubahan yang sangat cepat di segala bidang, kebutuhan akan nilainilai global serta standar intemasional menjadi kebutuhan dari setiap anggota komunitas global. Kebutuhan ini mau tidak mau juga menjadi tuntutan bagi Indonesia, sebagai anggota komunitas global, untuk memiliki sumber daya manusia dengan kualitas sesuai dengan standar yang dibutuhkan masyarakat global serta yang selalu mampu beradaptasi seiring dengan perubahan-perubahan yang terjadi. 
Kebutuhan akan sumber daya manusia dengan kualitas diatas menjadi tantangan bagi perguruan tinggi di Indonesia untuk tidak hanya memiliki tujuan untuk menghasilkan lulusan saja tetapi menghasilkan pribadi-pribadi yang berkualitas, suka dan selalu belajar(Life-long Learners). Indonesia membutuhkan sumber daya manusia yang dapat ikut berperan tidak hanya dalam masyarakat dengan lingkup lokal atau nasional saja tetapi sekaligus juga dalam lingkup internasional.

Untuk menjawab kebutuhan diatas, pendidikan secara umum termasuk dunia pendidikan tinggi di Indonesia pada khususnya perlu melihat kembali sistem, kurikulum maupun metode pengajaran yang dijalankan selama ini. Terobosanterobosan baru perlu dicari oleh dunia pendidikan untuk dapat menjawab tantangan diatas.

Salah satu terobosan baru yang dilakukan oleh Perguruan Tinggi Raharja adalah telah menciptakan dan menerapkan teknologi iLearning dalam proses pembelajaran bagi seluruh Pribadi Raharja. Pada dasarnya istilah iLearning (Integrated Learning) berasal dari pemikiran perkembangan teknologi iPad di Perguruan Tinggi Raharja. iLearning dikemas secara khusus untuk kegiatan proses pembelajaran secara online. Dari sistem belajar online, maka dapat diperoleh manfaat yaitu seperti fleksibilitas, jangkauan lebih luas, menghemat biaya, dan mempermudah penyempurnaan dan penyimpanan materi pembelajaran. Dalam iLearning terdapat istilah 4B, yaitu belajar, bekerja, berdoa, dan bermain. Melalui metode iLearning ini saya ingin menunjukkan konsep “paperless” yang mampu mengurangi penggunaan kertas di dalam kegiatan belajar mengajar [1].

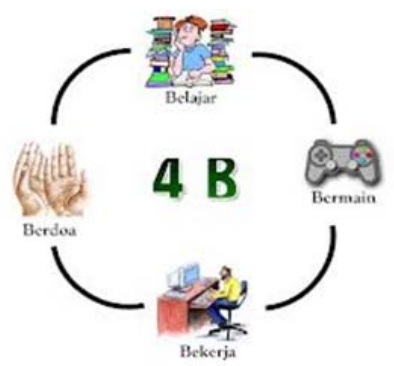

Gambar 1. Architecture iLearning 4B

Perguruan Tinggi Raharja juga merancang program portofolio mahasiswa atau yang dikenal dengan istilah "Integrated Raharja Multimedia E-portfolio (iRME)". iRME dicetuskan untuk mengakomodir dan memfasilitasi Pribadi Raharja dalam upaya lifetime pengumpulan portofolio pribadi[2]. Sebuah institusi dapat pula menunjuk sebuah unit di institusi tersebut untuk mengelola dan mewajibkan seluruh 
peserta didik membuat “Integrated Raharja Multimedia E-portfolio” yang memuat Curriculum Vitae (CV) yang berisi data diri dan sejarah belajar dari peserta didik secara keseluruhan dari awal hingga akhir masa studinya. Diharapkan melalui pemanfaatan “Integrated Raharja Multimedia E-portfolio (iRME)” ini Perguruan Tinggi Raharja dapat ikut berperan dalam menghasilkan sumber daya manusia Indonesia yang dapat menjawab kebutuhan bangsa Indonesia dalam melewati masa sulit saat ini maupun ikut berperan dalam pembangunan masyarakat global.

\section{PERMASALAHAN}

Seiring dengan pesatnya perkembangan terkini dituntut adanya informasi yang cepat, tepat dan akurat sehingga mengakibatkan persaingan yang semakin kompetitif. Ketatnya persaingan dalam perkembangan teknologi dan informasi yang ada menuntut suatu sistem menjadi lebih baik, cepat dan handal dalam menyelesaikan suatu permasalahan tertentu. Dengan berkembangnya teknologi dan kebutuhan akan informasi menyebabkan bertambah kompleksnya informasi yang harus diolah, sehingga kebutuhan pengguna akan jaringan komputer bersama-sama semakin diperlukan. Penggunaan jaringan secara bersama-sama ini bertumbuh membentuk jaringan komputer yang sangat besar tersebar diseluruh belahan muka bumi yang dikenal dengan nama internet yang bisa diakses dan dimanfaatkan untuk berbagai keperluan, oleh siapa saja, dimana saja dan kapan saja[3].

Pada saat ini seluruh perguruan tinggi memiliki sistem portofolio mahasiswa. Secara garis besar portofolio diartikan sebagai kompilasi bukti. Kompilasi bukti fisik mengenai aktivitas seseorang. Bukti yang merupakan hasil karya yang sangat berarti dalam menggambarkan kompetensi, begitu pula dengan Perguruan Tinggi Raharja yang telah memiliki sistem untuk membuat portofolio atau Curriculum Vitae (CV) untuk seluruh Pribadi Raharja. Namun masih terdapat permasalahan yang harus dihadapi saat ini. Dalam hal ini terdapat 5 (lima) permasalahan yang ada dalam sistem membuat portofolio atau Curriculum Vitae (CV) saat ini, yaitu permasalahan pertama dapat dikatakan masih belum optimal, hal tersebut dikarenakan pendataan yang masih manual. Permasalahan kedua yaitu dokumentasi banyak yang tercecer, permasalahan ketiga yaitu membutuhkan print CV yang banyak. Sedangkan permasalahan keempat yaitu memerlukan waktu dan biaya yang cukup banyak. Dan permasalahan yang terakhir yaitu ada kesulitan atau repot untuk mengumpulkan surat-surat penting yang nantinya akan kita bawa saat ingin melamar pekerjaan.

Dari permasalahan yang telah dijabarkan diatas, bahwa sistem untuk membuat portofolio atau Curriculum Vitae (CV) belum optimal. Sehingga didalamnya dapat 
diidentifikasikan secara keseluruhan terdapat 2 (dua) permasalahannya yang ada mengenai sistem yang berjalan saat ini yaitu untuk permasalahan pertama system masih manual. Dikatakan manual karena dalam pembuatan CV masih menggunakan kertas dan harus melakukan print out. Hal ini tentu sangat merepotkan dan membutuhkan biaya yang cukup besar, sementara itu setelah proses pengirim CV ke sebuah instansi pemerintahan maupun swasta melalui paper telah selesai dilaksanakan maka, paper tersebut diabaikan bahkan hanya menjadi arsip saja. Dengan cara manual pula seringkali kita membuat CV yang sama berulang kali sehingga banyak memakan waktu dan sarana lain. Tentu hal ini termasuk kedalam sifat paperless (pemborosan). Maka dari itu dapat disimpulkan bahwa pada poin permasalahan pertama tidak mencerminkan campus IT, yang notabenenya segala sesuatu bersifat online, praktis, dan mencerminkan green campus. Permasalahan kedua yaitu kesulitan dalam mengumpulkan dokumen-dokumen penting seperti sertifikat, transkip nilai, penghargaan maupun ijazah pendidikan yang telah ditempuh semasa sekolah. Bahkan terkadang para pelamar kerja juga harus memperbanyak (photocopy) dokumen-dokumen penting tersebut, dimasukkan ke dalam sebuah map yang nantinya akan mereka bawa pada saat ingin melamar pekerjaan di sebuah perusahaan.

Dari beberapa permasalahan diatas dapat disimpulkan secara detail menurut penjabaran tentang sistem pendukung yang tercantum dalam aplikasi Mind Mapping. Berikut tampilan perancangan Mind Mapping aplikasi iRME (Integrated Raharja Multimedi E-portfolio).
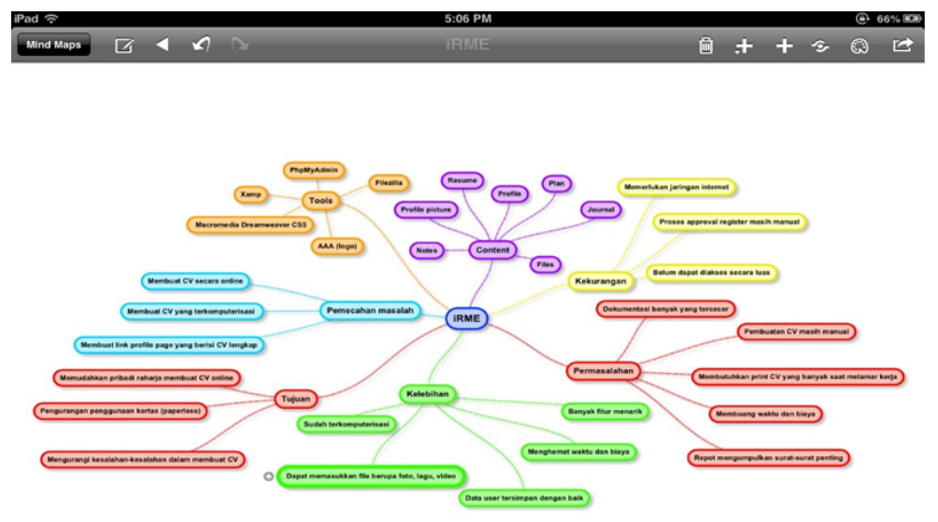

Gambar 2. Mind Mapping penjabaran sistem iRME

Tampak pada gambar diatas adalah Mind Mapping penjabaran perihal iRME (Integrated Raharja Multimedia E-portfolio). Maka, dengan adanya aplikasi iRME 
diharapkan sistem portofolio atau Curriculum Vitae (CV) untuk seluruh Pribadi Raharja dapat berjalan lebih baik lagi dan permasalahan-permasalahan dapat teratasi dengan adanya iRME ini.

\section{LITERATURE REVIEW}

Metode study pustaka dilakukan untuk menunjang metode wawancara dan observasi yang telah dilakukan. Pengumpulan informasi yang dibutuhkan dalam mencari referensi-referensi yang berhubungan dengan penelitian yang dilakukan.

Manfaat dari study pustaka (Literature Review) ini antara lain :

1 Mengidentifikasikan kesenjangan (identify gaps) dari penelitian ini.

2 Menghindari membuat ulang (reinventing the wheel) sehingga banyak menghemat waktu dan juga menghindari kesalahan- kesalahan yang pernah dilakukan oleh orang lain.

3 Mengidentifikasikan metode yang pernah dilakukan dan yang relevan terhadap penelitian ini.

4 Meneruskan apa yang penelitian sebelumnya telah dicapai sehingga dengan adanya studi pustaka ini, penelitian yang akan dilakukan dapat membangun di atas landasan (platform) dari pengetahuan atau ide yang sudah ada.

Banyak penelitian yang sebelumnya dilakukan mengenai penerimaan mahasiswa baru secara online dan penelitian lain yang berkaitan. Dalam upaya mengembangkan dan menyempurnakan penerimaan mahasiswa baru secara online ini perlu dilakukan studi pustaka (literature review) sebagai salah satu dari penerapan metode penelitian yang akan dilakukan. Diantaranya yaitu:

1 Penelitian yang dilakukan oleh Lorraine Stefani, Robin Mason, dan Chris Pegler dari Routledge yang berjudul "The Educational Potential of e-Portfolios: supporting personal development and reflective learning” tahun 2007. Penelitian ini membahas tentang potensi e-portfolio dalam pendidikan dengan sejumlah pendukung studi kasus dan sejumlah besar sumber daya online yang berguna dari Inggris dan di seluruh dunia. Ini adalah buku panduan praktis untuk membantu mereka yang tertarik dalam e-portfolio untuk belajar dan mengajar. Buku ini disusun dalam cara mengambil pembaca melalui tahapan e-portfolio implementasi yang akan diterapkan ke terbaru dari pengguna. Tema-tema 
mengikuti urutan logis dan memiliki fluiditas yang konsisten antara bab. Ini menyoroti kompleksitas dan masalah potensial pengguna mungkin menghadapi ketika menerapkan e-portfolio, sementara secara bersamaan mengidentifikasi keuntungan dan manfaat potensial untuk belajar dan mengajar yang dapat dialami dengan menggunakan e-portfolio[4].

2 Penelitian yang dilakukan oleh Ellen R. Cohn dan Bernard J. Hibbitts dari University of Pittsburgh yang berjudul "Beyond the Electronic Portfolio: A Lifetime Personal Web Space” tahun 2004. Penelitian ini membahas tentang portofolio elektronik (e-portfolio) adalah pendidikan tinggi yang baru "harus memilikinya” alat-acara-dan-kirim platform milenium. Ratusan lembaga akademik berbagai mempelajari, menggunakan, atau e-portofolio inovasi sistem. Memang, gerakan e-portfolio saat ini pemijahan komite universitas baru, modul pelatihan di kampus, buku, kampus-lebar kampanye informasi, pekerjaan, dan industri berpotensi menguntungkan bagi perusahaan perangkat lunak dan konsultan. Selain itu, fakultas dan lembaga yang mengadopsi eportofolio muncul canggih dan inovatif kepada para kolega dan mahasiswa. E-portfolio tampaknya “inheren” yang baik. Desainer instruksional memberitahu kita bahwa proses membangun sebuah e-portfolio merangsang siswa untuk terlibat dalam pemikiran reflektif. E-portfolio akan menyediakan lembaga akreditasi dengan bukti nyata bahwa siswa mencapai standar berbasis hasil. Lulusan baru akan menggunakan e-portfolio untuk menampilkan kreativitas dan prestasi, terutama untuk memperoleh keunggulan di pasar kerja. Tidak mengherankan, pusat karir penempatan universitas menganggap gerakan e-portfolio sebagai kesempatan untuk menghubungkan hasil akademik untuk tempat kerja[5].

3 Penelitian yang dilakukan oleh Trent Batson dari The Association for Authentic, Experiential and Evidence-Based Learning (AAEEBL) yang berjudul "12 Important Trends in the ePortfolio Industry for Education and for Learning” tahun 2012. Penelitian ini membahas tentang sebuah portofolio elektronik milik pelajar: sebuah aplikasi berbasis web yang dapat meng-upload dan menyimpan setiap jenis file untuk melayani sebagai bukti dalam presentasi dari e-portfolio, seperti untuk kelulusan atau untuk mendapatkan pekerjaan. Dengan demikian catatan elektronik dari prestasi yang dapat terus disortir dan dimusnahkan dari waktu ke waktu. Ini adalah repositori aktif dengan alat manajemen banyak yang dapat menghasilkan presentasi web untuk tujuan tertentu, itu adalah resume pembuat dengan bukti terkait. E-portfolios memungkinkan bergerak dari pendidikan (pendidik sebagai agen aktif) untuk belajar. "Dalam waktu pengetahuan stabil, mengajar, dalam waktu pengetahuan 
cepat berubah, belajar. Ini adalah waktu untuk belajar: Mulai semua pemikiran berdasarkan pertimbangan tentang belajar. Pendidikan menganggap satu set bidang pengetahuan, membatasi penemuan pelajar itu, bidang di mana semua pengetahuan telah ditemukan dan dianalisa, melainkan menganggap siswa akan ditindaklanjuti oleh pendidik bukan mahasiswa / pelajar bertindak atas pengetahuan itu menganggap satu jalur untuk semua peserta didik fokus pada belajar, e-portfolios memungkinkan pendidik untuk melakukan, membuka pengalaman belajar. [6].

4 Penelitian yang dilakukan oleh Robert C. Reardon, Jill A. Lumsden, dan Katie E. Meyer dari NASPA Journal yang berjudul "Developing an E-Portfolio Program: Providing a Comprehensive Tool for Student Development, Reflection, and Integration” pada tahun 2005. Penelitian ini membahas tentang pengembangan portofolio mahasiswa adalah area minat dan aktivitas di banyak kampus. Program e-portfolio memiliki kegiatan yang memungkinkan siswa untuk mempelajari dan mendokumentasikan sembilan keterampilan umum yang berkaitan dengan kehidupan / pengembangan karir, yang kemudian dapat dibagi dengan pengusaha, dosen, dan pengguna dirujuk lainnya. Ini menyediakan kerangka kerja bagi siswa untuk merenungkan dan mengintegrasikan pengalaman penuh pembelajaran. Hasil dari proses evaluasi secara singkat dijelaskan, diikuti dengan peninjauan e-portfolio prestasi program, pekerjaan yang sedang berlangsung, dan kemungkinan masa depan[7].

5 Penelitian yang dilakukan oleh Rano Kurniawan, Henderi, dan Fitria Nursetianingsih yang berjudul "Penggunaan Ipad Mendukung Pembelajaran Pada Mahasiswa Ilearning” pada tahun 2012 di Perguruan Tinggi Raharja. Penelitian ini membahas tentang iLearning (Integrated Learning) dapat diartikan sebagai metode pembelajaran yang menyeimbangkan antara otak, gerakan dan kecerdasan. iLearning berkaitan dengan 4B (Belajar, Bermain, Bekerja, Berdoa) dan realisasinya menyatu dalam kehidupan sehari-hari. Untuk mendukung keefektifan metode pembelajaran iLearning perlu akan adanya sarana pendukung sebagai standarisasinya. Di dalam iPad terdapat berbagai aplikasi yang mendukung kegiatan belajar, bermain, bekerja, maupun berdoa. Dengan adanya sarana iPad hal ini dapat memudahkan pembelajaran iLearning dan menciptakan integritas yang baik untuk metode pembelajaran. Dengan adanya sarana pendukung ini diharapkan mahasiswa memiliki kemampuan lebih dan selalu up to date dengan perkembangan ilmu pengetahuan dan teknologi, serta berpartisipasi menuangkan ide-ide kreatif untuk pengembangan teknologi kearah yang lebih maju lagi[8]. 
6 Penelitian yang dilakukan oleh Untung Rahardja, Dina Fitria Murad, dan Siti Chalifatullah dari Perguruan Tinggi Raharja, Indonesia pada tahun 2008 yang berjudul "Periodic Historical System Sebagai Evaluasi Strategis Dalam Mendukung Pengambilan Keputusan Manajemen”. Penelitian ini menjelaskan perkembangan sistem informasi memiliki laju pertumbuhan yang sangat pesat, terutama sebagai media untuk memberikan informasi yang cepat dan akurat. Banyak perusahaan maupun organisasi menggunakan sistem informasi sebagai bahan evaluasi kinerja. Sebuah sistem informasi harus memiliki kemampuan yang baik, yaitu mampu memberikan informasi secara cepat dan akurat. Seiring berjalannya waktu maka informasi yang didapat akan semakin meningkat, tetapi informasi tersebut belum dapat terekam dan tersimpan dengan baik kedalam sebuah history sistem, dimana dapat merekam dan menyimpan seluruh informasi yang lama ataupun yang baru serta mampu memberikan informasi dari waktu kewaktu, walaupun informasi tersebut telah lampau, manajemen juga dapat menggunakan sistem tersebut guna membantu proses evaluasi strategis manajemen. Untuk mengatasi permasalahan ini, dibutuhkan suatu metodologi yang disebut Periodic Historical System(PHS). PHS didefinisikan sebagai teknik pengumpulan, pengintegrasian dan penyimpanan data yang bertujuan untuk memberikan informasi manajemen yang akurat dari waktu ke waktu serta bermanfaat untuk evaluasi manajemen dalam pengambilan keputusan. Diidentifikasikan 5 (lima) masalah yang timbul pada sistem informasi, mendefinisikan metode baru yang disebut PHS, menentukan 4 (empat) ciri khas dari PHS, merancang algoritma PHS, serta menguraikan 5 (lima) manfaat dari penerapan PHS. Aplikasi juga diurai dengan rincian database yang diperlukan serta flowchart diagram. Dengan metodologi PHS ini dapat menjadi sebuah evaluasi terkini dalam mendukung kepentingan manajemen dalam pengambilan keputusan yang akurat[9].

7 Penelitian yang dilakukan oleh Aris Martono, Padeli, dan Dina Fitria Murad dari Perguruan Tinggi Raharja, Indonesia pada tahun 2009 yang berjudul “Pengembangan Sistem Database Penempatan Tenaga Kerja Berbasis Web”. Penelitian ini bertujuan untuk memudahkan penempatan para pencari kerja pada perusahaan yang membutuhkan sesuai dengan persyaratan yang ditentukan sehingga perusahaan mendapatkan tenaga kerja profesional siap pakai sesuai dengan profesinya melalui internet. Penelitian ini untuk memudahkan pihak pengguna untuk mengakses secara mobile; penyedia lowongan kerja mempunyai banyak pilihan para pencari kerja; para pencari kerja memiliki banyak pilihan lowongan kerja yang diharapkan; lembaga penyedia tenaga kerja perguruan tinggi, jasa tenaga kerja swasta dll akan 
mudah memantau informasi pasar kerja secara aktual; Lembaga pemerintah terkait selaku pembuat kebijakan akan menciptakan kebijakan ketenagakerjaan yang bersifat kompetitif; Menciptakan budaya baru yang menghargai dan menghormati teknologi informasi sebagai alat untuk aktivitas bisnis; Diperlukan investasi awal untuk mengembangkan sistem database penempatan tenaga kerja berbasis web; dan dibentuk organisasi dan para personil yang bertugas dan bertanggung-jawab serta diperlukan biayaoverhead maupun operasionalnya[10].

8 Penelitian yang dilakukan oleh Untung Rahardja, Henderi, dan Rosdiana dari Perguruan Tinggi Raharja, Indonesia pada tahun 2007 yang berjudul "Raharja Multimedia Edutainment (RME) Menunjang Proses Belajar Mengajar di Perguruan Tinggi Raharja”. Penelitian ini menjelaskan pada dasarnya istilah Raharja Multimedia Edutainment (RME) berasal dari 3 unsur pokok yaitu Raharja, Multimedia, dan Edutainment. Dengan demikian, pengertian terhadap ketiga unsur-unsur pokok ini akan sangat membantu dalam memahami RME. Istilah Raharja Multimedia Edutainment mengandung pengertian bahwa Perguruan Tinggi Raharja dalam mengembangkan konsep proses pembelajaran berbasis multimedia yang dikemas secara entertainment sehingga menghadirkan konsep Interactive Digital Multimedia Learning (IDML) yang menyentuh kekuatan panca indra meliputi teks, gambar, suara untuk memberikan pelayanan dalam proses belajar mengajar kepada seluruh civitas akademika dan secara terus menerus melakukan perbaikan (countinues improvment) menuju kesempurnaan dalam materi bahan ajar yang selalu berkembang seiring dengan kemajuan dan perkembangan teknologi[11].

9 Penelitian yang dilakukan oleh Prabowo Pudjo Widodo, Maimunah, dan Henderi dari Perguruan Tinggi Raharja, Indonesia pada tahun 2009 yang berjudul "Kajian Persepsi PenggunaTeknologi Pembelajaran Raharja Multimedia Edutainment (RME) Menggunakan Metode Technology Acceptance Model”. Penelitian ini membahas tentang produk teknologi informasi yang telah diciptakan dan digunakan oleh Perguruan Tinggi Raharja tersebut adalah Raharja Multimedia Edutainment (RME). Teknologi ini digunakan untuk mendukung dan memperlancar pelaksanaan kegiatan belajar mengajar, dan memenuhi kebutuhan informasi yang berhubungan dengannya. Sehubungan dengan hal itu, penelitian ini bertujuan untuk mengetahui faktorfaktor yang mempengaruhi diterima dengan baik atau tidaknya RME oleh penggunanya. Juga ingin diketahui hubungan antara faktor-faktor yang mempengaruhi penerimaan RME. Model yang digunakan untuk mengetahui penerimaan RME pada penelitian ini adalah model TAM (Technology 
Acceptance Model). Model TAM secara rinci menjelaskan penerimaan teknologi informasi (TI) dengan dimensi-dimensi tertentu yang dapat mempengaruhi penerimaan teknologi oleh pengguna. Model ini menempatkan faktor sikap dan tiap-tiap perilaku pengguna dengan menggunakan dua variabel utama yaitu kemanfaatan (usefulness) dan kemudahan penggunaan (easy of use)[12].

10 Penelitian yang dilakukan oleh Arlinah Imam Rahardjo dari UK Petra yang berjudul“"Electronic Student Portofolio” : Menjawab Tantangan Kebutuhan Lulusan Perguruan Tinggi Indonesia”. Penelitian ini membahas tentang portfolio merupakan salah satu alat yang dapat dimanfaatkan untuk memberi perhatian pada potensi-potensi yang dimiliki oleh para peserta didik sebagai pribadi yang unik dan memberikan motivasi untuk terus belajar dan mengembangkan potensi dan minatnya. Portfolio di dunia pendidikan ini dikenal dengan istilah “Student Portfolio” yang berlaku bagi peserta didik sekolah dasar, sekolah menengah ataupun perguruan tinggi. Secara umum "Student Portfolio" adalah catatan dan kumpulan karya peserta didik yang menggambarkan sejarah proses belajar mahasiswa, usaha-usaha, pertumbuhan, perubahan-perubahan yang dialami serta prestasi yang dicapai selama menempuh pendidikan di perguruan tinggi. Sejarah tersebut digambarkan melalui proses pengumpulan, seleksi, penulisan dan refleksi diri atas segala kegiatan yang diikuti, karya yang dibuat[13].

11 Dari sepuluh Literature Review yang ada, telah banyak penelitian mengenai The Educational Potential of e-Portfolios: supporting personal development and reflective learning, Beyond the Electronic Portfolio: A Lifetime Personal Web Space, 12 Important Trends in the ePortfolio Industry for Education and for Learning, Developing an E-Portfolio Program: Providing a Comprehensive Tool for Student Development, Reflection, and Integration, Penggunaan Ipad Mendukung Pembelajaran Pada Mahasiswa Ilearning, Periodic Historical System Sebagai Evaluasi Strategis Dalam Mendukung Pengambilan Keputusan Manajemen, Pengembangan Sistem Database Penempatan Tenaga Kerja Berbasis Web, Raharja Multimedia Edutainment (RME) Menunjang Proses Belajar Mengajar di Perguruan Tinggi Raharja, Kajian Persepsi Pengguna Teknologi Pembelajaran Raharja Multimedia Edutainment (RME) Menggunakan Metode Technology Acceptance Model, Electronic Student Portofolio” : Menjawab Tantangan Kebutuhan Lulusan Perguruan Tinggi Indonesia. Namun dapat disimpulkan pula bahwa belum ada peneliti yang secara khusus membahas mengenai portofolio mahasiswa dengan menggunakan e-portfolio pada perguruan tinggi. 


\section{HASIL DAN PEMBAHASAN}

Untuk mengatasi berbagai masalah diatas, maka diperlukan proses yang cepat, handal dan efisien dalam mengakses seluruh data yang banyak dan tidak teratur di dalam media penyimpanan yang berupa sebuah website, terlebih untuk suatu sistem informasi yang akurat.

Bila kita lihat pada sistem berjalan bahwa dalam membuat berbentuk CV yang fungsional. CV fungsional adalah CV yang biasanya mencantumkan daftar kemampuan dan keahlian plus sejarah karir yang panjang. Padahal CV semacam itu sangat klasik dan membosankan dibaca. Kita butuh perubahan karena saat ini dunia dan perkembangan teknologi sudah begitu maju dan akan selalu membutuhkan perkembangan dari berbagai sisi.

Berdasarkan analisa dari segi kekurangan serta kebutuhan saat ini, kebutuhan terhadap sistem hendaknya sistem dapat mudah diakses dan user (Pribadi Raharja) mendapatkan pembelajaran dalam membuat portofolio atau CV secara optimal yang dibutuhkan oleh seluruh civitas akademik di perguruan tiggi sehingga dapat memaksimalkan berbagaai bentuk pembelajaran dalam membuat portofolio kepada seluruh civitas akademik dengan baik.

Untuk mengatasi berbagai masalah, maka diperlukan alternatif pemecahan masalah. Yaitu pemecahan masalah yang pertama, untuk membuat portofolio atau Curriculum Vitae(CV) dengan menggunakan iRME (Integrated Raharja Multimedia E-portfolio).

Sistem iRME merupakan media pendukung dalam mengakomodir dan memfasilitasi Pribadi Raharja dalam upaya pengumpulan portofolio pribadi dalam sebuah website sehingga bisa diakses oleh jaringan internet. Pribadi Raharja dapat mengisikan informasi mengenai data-data pribadi mereka dan data-data tersebut akan tersimpan dengan rapi dan dapat di publish. Sehingga memudahkan Pribadi Raharja dalam membuat portofolio pribadi atau CV yang dapat diakses dimanapun dan kapanpun tanpa perlu melakukan print out yang banyak untuk menunjukkan CV yang mereka punya.

Pemecahan masalah yang kedua, yaitu dalam iRME terdapat berbagai feature pendukung, seperti adanya fasilitas untuk mengisi resume yang ada pada kolom "Content”. Disana terdapatContact Information yang merupakan untuk informasi pribadi, dalam kolom “Files” Pribadi Raharja juga dapat memasukkan files berupa foto-foto sertifikat, dokumen-dokumen penting atau berbagai penghargaan yang dimiliki oleh Pribadi Raharja. Sehingga dokumentasi Pribadi Raharja tidak hilang atau tercecer, hanya tinggal memberikan sebuah link profile page yang ada dalam iRME, maka akan ditampilkan semua CV yang sudah dibuat oleh Pribadi Raharja. 


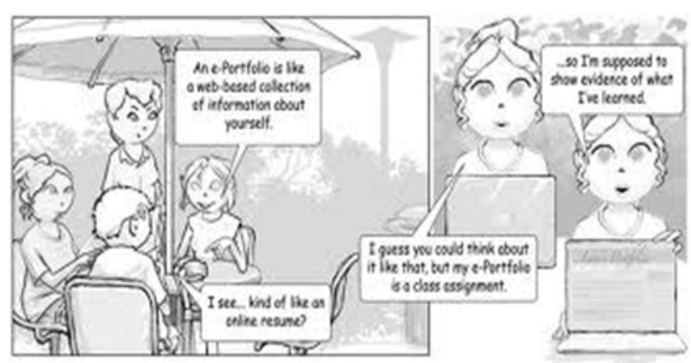

Gambar 3. Figure ilustrasi portofolio mahasiswa

Pada gambar figure ilustrasi portofolio mahasiswa dalam membuat $\mathrm{CV}$ online dapat memudahkan Pribadi Raharja untuk membuat sebuah CV yang berkualitas, dapat dilakukan pula dengan jalan alternatif yang memudahkan untuk melakukan proses tersebut, yaitu melaluiflowchart. Dan dibawah ini merupakan gambaran flowchart alur program yang berjalan dari sistem untuk membuat e-portofolio atau CV online.

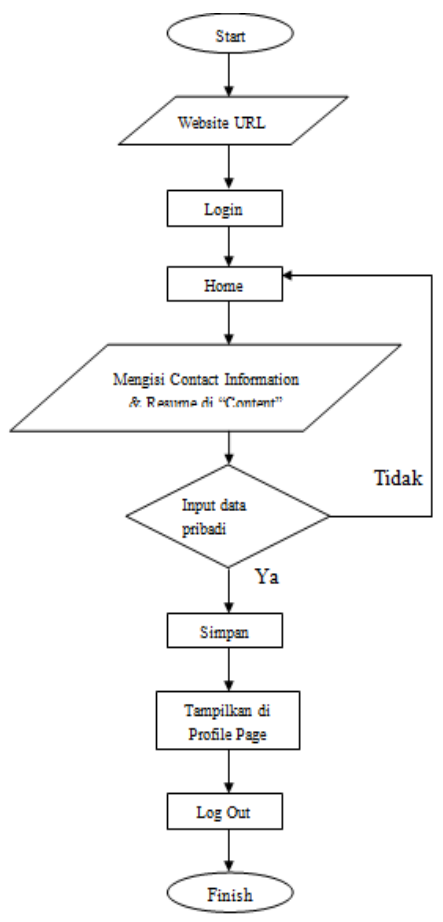

Gambar 4. Flowchart alur sistem iRME 
Gambar flowchart diatas menjabarkan proses untuk memulai dan mengisi data-data pribadi mahasiswa yang berupa Curriculum Vitae (CV) di iRME hingga selesai. Langkah pertama membuat CV di iRME adalah dengan masuk ke dalam website iRME, lalu login, setelah itu masuk dalam "Home” disana terdapat fitur "Content” untuk mengisi resume, kemudian masukkan data-data pribadi, lalu datadata tersebut disimpan. Setelah disimpan, data-data Pribadi Raharja yang berupa CV lengkap dapat ditampilkan di “Profile Page”. Diagram rancangan sistem yang diusulkan pun dapat pula dijabarkan melalui Use Case Diagram:

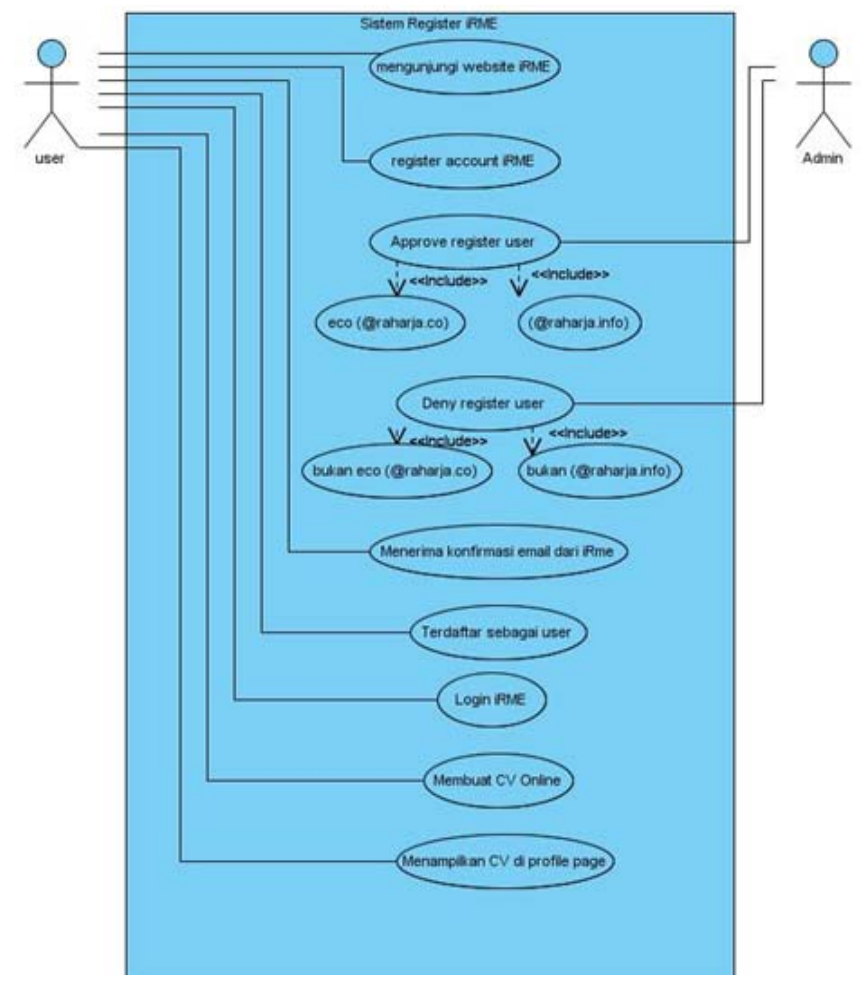

Gambar 5. Use case diagram iRME

Pada dasarnya use case merupakan gambaran dari proses sistem secara keseluruhan yang melibatkan actor dalam hal penggunaan. Dalam use case diagram ini terdapat 2 actor yang terlibat didalam sistem iRME, dimana masing-masing actor memiliki hak akses yang berbeda. Hak akses admin yaitu seperti melakukan approve kepada new user yang melakukan register iRME dengan menggunakan email eco 
(@raharja.co) atau rinfo (@raharja.info).Hak akses untuk useryaitu dapat membuat CV online hingga menampilkan CV mereka tersebut di "Profile Page" yang ada di iRME.

\section{Listing Program}

Dibawah ini merupakan view detail listing program Integrated Raharja Multimedia E-portfolio (iRME), yaitu sebuah script dari Dashboard iRME. Berikut listing programnya:

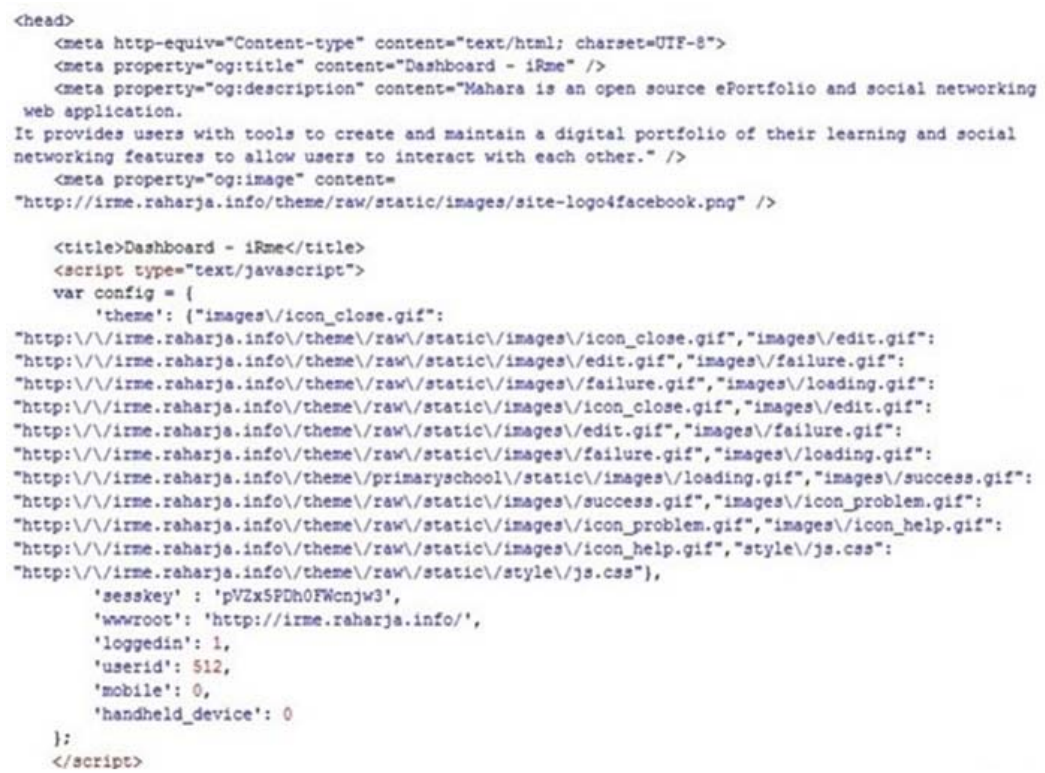

Gambar 6. Listing program sistem iRME

\section{KESIMPULAN}

Berdasarkan hasil penelitian ini diharapkan dapat bermanfaat oleh seluruh perguruan tinggi dan masyarakat luas sebagai media untuk membuat portofolio mahasiswa atau Curriculum Vitae (CV) secara online. Selain itu dapat memberikan informasi yang akurat dan up to datesehingga informasi yang didapatkan relevan dan sesuai dengan kebutuhan. Dan hasil penelitian ini dapat dijadikan referensi bagi 
penelitian sejenis dimasa yang akan datang. Namun masih terdapat 5 (lima) permasalahan yang ada dalam sistem untuk membuat portofolio mahasiswa saat ini, sehingga dapat dirumuskan permasalahan secara keseluruhan, yang secara detail menurut penjabarannya dicantumkan dalam aplikasi Mind Mapping. Terdapat pula beberapaliterature review yang ada, diantaranya The Educational Potential of ePortfolios: supporting personal development and reflective learning, Beyond the Electronic Portfolio: A Lifetime Personal Web Space, 12 Important Trends in the ePortfolio Industry for Education and for Learning, maupun Electronic Student Portofolio" : Menjawab Tantangan Kebutuhan Lulusan Perguruan Tinggi Indonesia. Pada implementasinya ditampilkan prototype iRME. Terdapat pula jalan alternatif yang memudahkan untuk melakukan proses membuat portofolio, yaitu melaluiflowchart, use case diagram dan view detail listing mengenai iRME. Sehingga dapat disimpulkan bahwa, iRME merupakan media pendukung dalam mengakomodir dan memfasilitasi Pribadi Raharja dalam upaya pengumpulan portofolio pribadi, serta menjadi tempat yang tepat untuk membuat CV yang berkualitas.

\section{DAFTAR PUSTAKA}

[1] Rahardja, Untung. 2011. "Definisi iLearning”.

[2] Rahardja, Untung. “Definisi Integrated Raharja Multimedia E-portfolio (iRME). Diakses pada 22 Januari 2013 dari: http://untungrahardja.ilearning.me/2013/ 01/22/., Januari 2013.

[3] Rahardja, Untung, Nur Azizah, Santika Dewi. 2013. “Sistem Pelayanan Dukungan Role Online System Ticketing Raharja (ROOSTER) Dengan Menggunakan E-Ticket”. CCIT Journal ISSN : 1978-8282 Vol. 7 No. 1. Tangerang : Perguruan Tinggi Raharja.

[4] Stefani, Lorraine, Robin Mason, Chris Pegler. 2007. “The Educational Potential of e-Portfolios: supporting personal development and reflective learning”. New York and Canada : Routledge.

[5] Cohn, R. Ellen, Bernard J Hibbitts. 2004. "Beyond the Electronic Portfolio: A Lifetime Personal Web Space”. Pennsylvania: University of Pittsburgh.

[6] Batson, Trent. 2012. "12 Important Trends in the ePortfolio Industry for Education and for Learning”. USA: The Association for Authentic, Experiential and Evidence-Based Learning (AAEEBL).

[7] Reardon, C. Robert, Jill A. Lumsden, Katie E. Meyer. 2005. "Developing an E-Portfolio Program: Providing a Comprehensive Tool for Student 
Development, Reflection, and Integration”. NASPA Journal, Vol. 42, No. 3, pp. 368.

[8] Kurniawan, Rano, Henderi, Fitria Nursetianingsih. 2012. "Penggunaan Ipad Mendukung Pembelajaran Pada Mahasiswa Ilearning”. CCIT Journal ISSN : Vol. 6 No. 1. Tangerang : Perguruan Tinggi Raharja.

[9] Rahardja, Untung, Dina Fitria Murad, Siti Chalifatullah. 2008. "Periodic Historical System Sebagai Evaluasi Strategis Dalam Mendukung Pengambilan Keputusan Manajemen”. CCIT Journal ISSN : 1978-8282 Vol. 1 No. 2. Tangerang: Perguruan Tinggi Raharja.

[10] Martono, Aris, Padeli, Dina Fitria Murad. 2009. "Pengembangan Sistem Database Penempatan Tenaga Kerja Berbasis Web”. CCIT Journal ISSN : 1978-8282 Vol. 2 No. 3. Tangerang : Perguruan Tinggi Raharja.

[11] Rahardja, Untung, Henderi, Rosdiana. 2007. "Raharja Multimedia Edutainment(RME) Menunjang Proses Belajar Mengajar di Perguruan Tinggi Raharja”. CCIT Journal ISSN : 1412-1344. Edisi 7TH IV / April. Tangerang : Perguruan Tinggi Raharja.

[12] Widodo, Pudjo Prabowo, Maimunah, Henderi. 2009. “Kajian Persepsi Pengguna Teknologi Pembelajaran Raharja Multimedia Edutainment(RME) Menggunakan Metode Technology Acceptance Model”. CCIT Journal ISSN : 1978-8282 Vol. 2 No. 3. Tangerang : Perguruan Tinggi Raharja.

[13] Rahardjo, Imam Arlinah. 2003. "Electronic Student Portofolio” : Menjawab Tantangan Kebutuhan Lulusan Perguruan Tinggi Indonesia”. Surabaya : Universitas Kristen Petra (Cakrawala Pendidikan: E-Learning dalam pendidikan hal. 419-433). 